\title{
EFFECT OF ROOTSTOCK ON REFRACTION OF FORCED FRESH PEPPER (CAPSICUM ANNUUM L.)
}

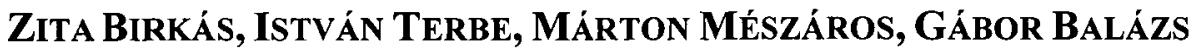

\author{
Szent István University, Department of Vegetable and MushroomGrowing \\ H-1118 Budapest, Villányi út 29-43. \\ birkas.zita@phd.uni-szie.hu
}

\begin{abstract}
Fresh pepper (Capsicum annuum L.) production has a great tradition in Hungary. In 2014 fresh pepper was forced on $1600 \mathrm{ha}$, which reached approximately a $10 \mathrm{~kg} / \mathrm{m}^{2}$ yield. While in case of tomato, which belongs to the Solanaceae family, the use of grafted plants is relevant today, the practice of grafted plants in the cultivation of hungaricum fresh pepper is a not so known and used method. Therefore, the main objective of the experiment was to study the qualitative changes in response to grafting and to determine the appropriate rootstock - scion combination. The experiment was set up in unheated plastic house at the research garden of Szent István University in Soroksár. Combination of two fresh pepper varieties SV 9702 (white type) and Karpex (kapia type) and two rootstocks Snooker and Capsifort were tested in soil and soilless culture. For soil culture the soil of the plastic house and for the soilless culture coconut fiber slabs was used. Grafted and non-grafted white type fresh peppers were placed at a row width and plant spacing of $110+40 \times 33 \mathrm{~cm}(4$ plants per $\mathrm{m}^{2}$ ) while kapia at $110+40 \times 25\left(5.3\right.$ plant per $\mathrm{m}^{2}$ ). After the picking the Brix content was determined at the analytical laboratory of the department. From each repeat, 6 fruits were blended and measured with manual digital refractometer (PAL-1, ATAGO). After our studies both Snooker and Capsifort rootstock are recommended in combination of SV 9702 white type and Karpex kapia type fresh pepper in soilless culture.
\end{abstract}

Keywords: fresh pepper, rootstock, grafting, forcing, brix

\section{INTRODUCTION}

Fresh pepper (Capsicum annuum L.) production has a great tradition in Hungary. In 2014, fresh pepper was forced on $1600 \mathrm{ha}$, which reached approximately a $10 \mathrm{~kg} / \mathrm{m}^{2}$ yield. Furthermore its open field production is also significant. The spread of plastic houses and the monoculture led to the increase of grafting vegetable crops around the 1960s (NAGY, 2005).

In Hungary and also in the world, the soil salinity causes problems, while most species of grown vegetables, especially fresh pepper, are salt sensitive. According to FAO data, 6\% of the world's soil is salt-sensitive. In our country mainly the high salt content of the irrigation water cause harmful salt accumulation in soils. Through the accumulated salt the plant can absorb less water, hereby the nutrition uptake decreases (BALÁZS, 2011).

Nowadays, grafting has been increasingly popular in the production of vegetables. According to literature data, the practice of grafting has increased significantly in the recent years in abroad. In some Asiain countries grafting enjoys great popularity and nowadays the Europian countries are also increasing the demand for grafted seedlings (LEE, 1994; FERNÁNDEZ-GARCIA ET AL., 2004). By the use of rootstock, the tolerance to low (BULDER ET AL., 1990) and high temperatures can be increased (RIVERO ET AL., 2003). The aim of the producers, which is an effective long-term field utilization, is often intersected by soil borne diseases and pests against which the solution is soil disinfection, soilless cultivation and grafting (POGONYI AND PÉK, 2004). Grafted transplant shows better reaction to low soil temperature and high soil salt content (EDELSTEIN, 2004). Latest 
studies proved, that the abiotic stress tolerance of grafted fresh pepper improved (PENELLA, 2014).

According to GARNER (1979), grafting has mainly three disadvantages, which are the incompatibility, costliness and possible quality loss. It is important to note that the quality loss occurs commonly because the producers do not take account the changed water and nutrition demand of grafted plants (SEDLÁK, 1993).

While in case of tomato, which belongs to the Solanaceae family, the use of grafted plants is relevant today, the practice of grafted plants in cultivation hungaricum fresh pepper is not so known and used method. Therefore, the main objective of the experiment was to study the refraction changes in response to grafting and to determine appropriate rootstock - scion combination.

\section{MATERIAL AND METHOD}

The experiment was set up in unheated plastic house at the research garden of Szent István University in Soroksár. Combination of two fresh pepper varieties SV 9702 (white type) and Karpex (kapia type) and two rootstocks Snooker and Capsifort were tested in soil and in soilless culture. For soil culture the soil of the plastic house, and for the soilless culture coconut fiber slabs were used. Non-grafted and grafted transplants were planted out in 4 repeats in 18th May using intensive technology (soil mulch, dripping tube/dripping irrigation system, training system). Table 1 contains the sowing date of seeds for grafted and non-grafted transplants.

Table 1. Sowing and grafting dates (2015)

\begin{tabular}{|c|c|c|}
\hline Grafted & Peat & Rockwool \\
\hline scions & 20.03 & 27.03 \\
\hline rootstock & 18.03 & 25.03 \\
\hline Graftingdate & 23.04 & 28.04 \\
\hline Non-grafted & Peat & Rockwool \\
\hline SV 9702/ Karpex & 27.03 & 03.04 \\
\hline
\end{tabular}

Grafted and non-grafted white type fresh pepper were placed at row width and plant spacing of $110+40 \times 33 \mathrm{~cm}\left(4\right.$ plants per $\left.\mathrm{m}^{2}\right)$ while kapia at $110+40 \times 25(5.3$ plants per $\mathrm{m}^{2}$ ). During the growing season two main stem was evolved twisted constantly to the training system and slightly pruned. In case of the white type, the fruits were harvested in economic ripeness seven times (14th July, 23rd July, 30th July, 6th August, 13th August, 25th August, 8th September), while the kapia type in biological ripeness 5 times (25th August, 3rd September, 10th September, 28th September, 20th October). After the picking the refraction was measured at the analytical laboratory of the department. From each repeat 6 fruits were blended and measured with manual digital refractometer (PAL1, ATAGO). The results granted in ${ }^{\circ}$ Brix. 


\section{RESULTS}

After all pickings, the Brix content was determined at the analytical laboratory of the department by manual digital refractometer. From each repeat 6 fruits were blended and measured. After the average refraction values were calculated (Figures 1-4).

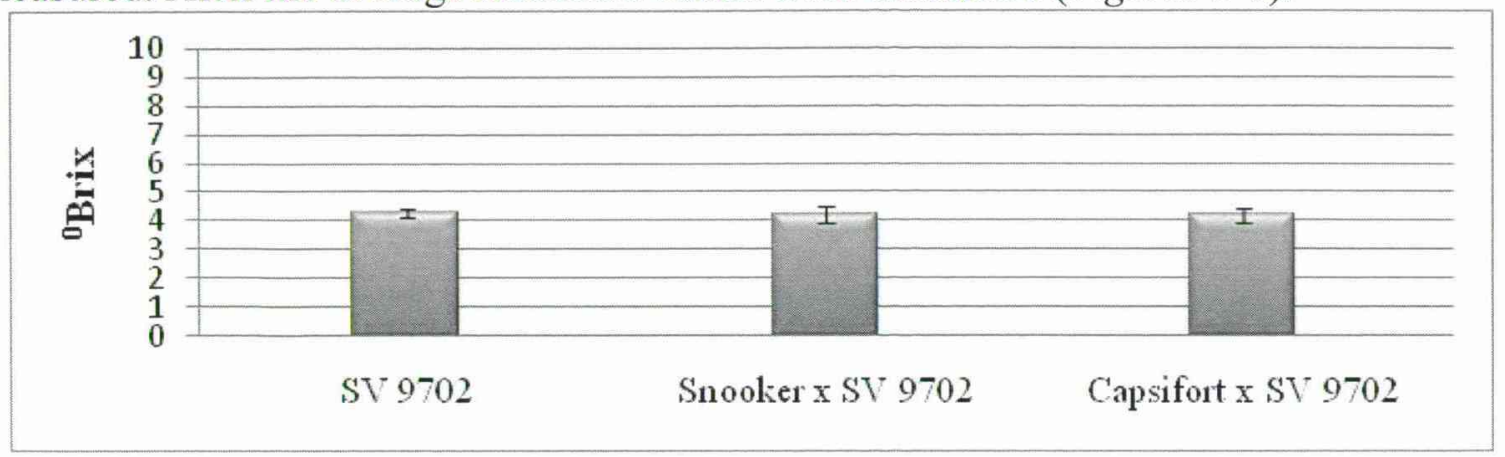

Figure 1. Refraction of white type fresh pepper in soilless culture (2015)

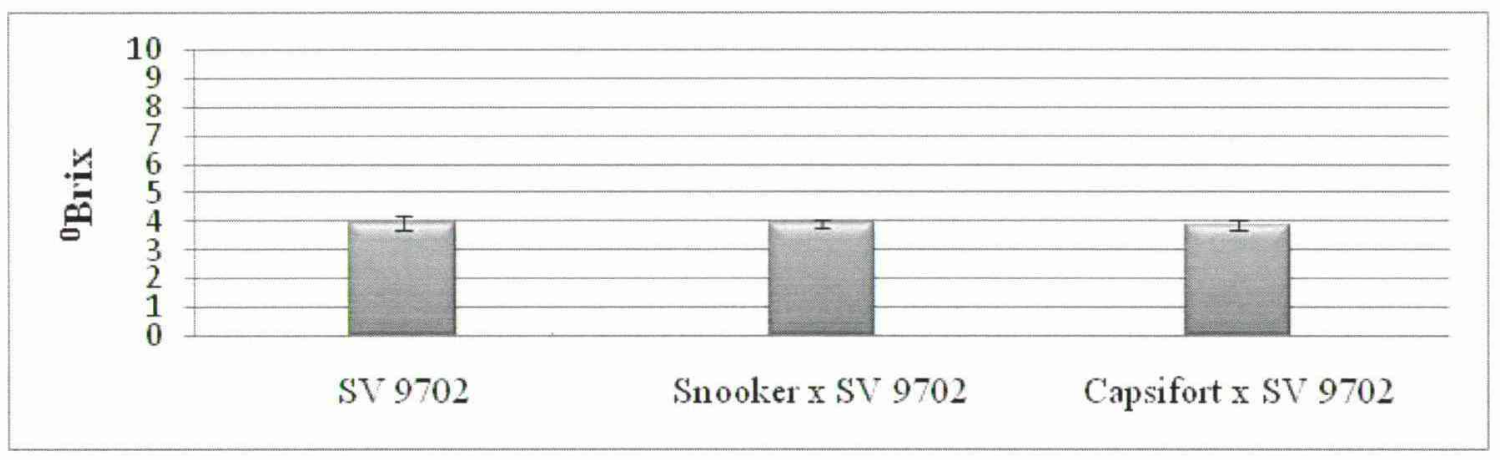

Figure 2. Refraction of white type fresh pepper in soil culture (2015)

Based on the results, it can be seen, that the refraction of white type fresh pepper was higher in soilless culture than in soil culture. Both in soil culture and in soilless culture, there were no significant differences in refraction detected between the grafted and nongrafted plants. The graft combinations Snooker x SV 9702 and Capsifort x SV 9702 had the same refraction on the different growing medias (Figures 1-2).

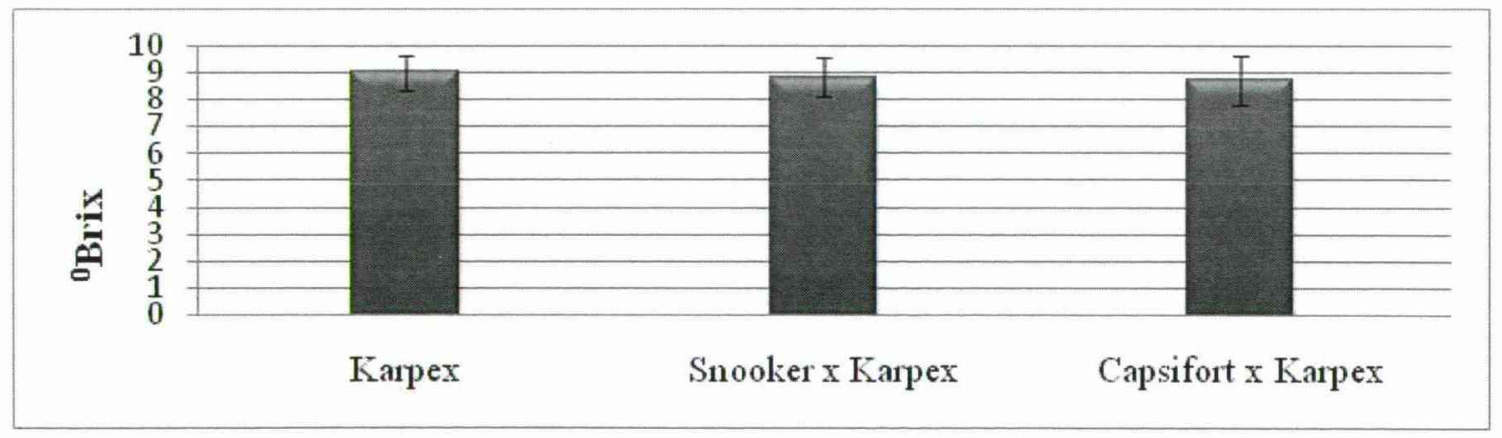

Figure 3. Refraction of kapia type fresh pepper in soilless culture (2015) 


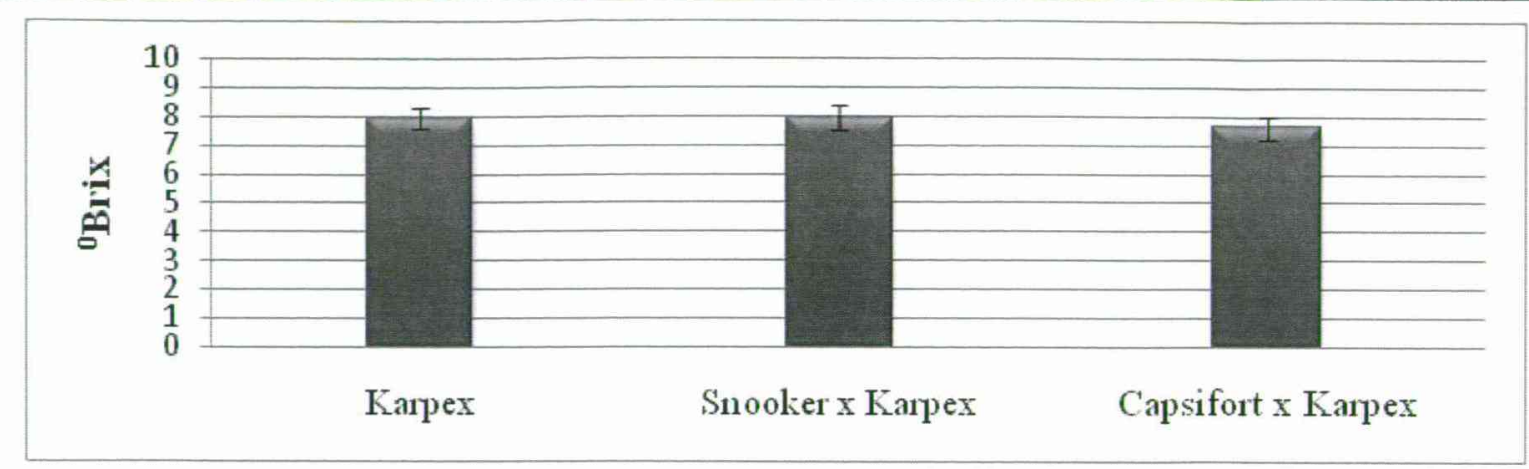

Figure 4. Refraction of kapia type fresh pepper in soilless culture (2015)

In the case of kapia type fresh pepper, grafting had no significant effect on refraction both in soil and soilless culture. In soilless culture, higher refraction was measured than in soil culture. The difference is approximately $10 \%$. On both growing media Capsifort $x$ Karpex showed lower refraction than Snooker $x$ Karpex and own rooted Karpex (Figures 3-4).

\section{CONCLUSIONS}

During the measurement of refraction from the average Brix value were determined that due to grafting slight decrease occurred, both in soil and soilless culture. Between the grafting on different rootstocks Snooker and Capsifort resulted the same which can be explained that both rootstocks have approximately the same effect on the scions.

Although the summer of 2015 was hot, it had no effect on the Brix values of the pickings.

Soilless culture has nowadays many advantages (higher yield, no disinfection from soil) and disadvantages (high labour). While it has higher investment cost in the case of both varieties, soilless culture is recommended.

Grafting of fresh pepper is increasing. Many varieties are present on the market but there are limited rootstock varieties. After our studies both Snooker and Capsifort rootstock are recommended in combination of SV 9702 white type and Karpex kapia type fresh pepper.

\section{REFERENCES}

Balázs, G., Kappel, N., FeKete, D., BöHm, V. (2011): Az oltás hatása a görögdinnye produktivitására. Kertgazdaság 43(4): 3-8.

Bulder, H.A.M., Van Hasselt, P.R., KuiPe, P.J.C., SpeeK, E.J., Den NiJs, A.P.M. 1990): The effect of lowroottemperatureingrowth and lipidcomposition of lowtolerantrootstockgenotypesforcucumber. J. Plant Physiol. 138: 661-666.

Edelstein, M., Burger, Y., Horev, C., Porat, A., Meir, A., Cohen, R. (2004): Assesingtheeffect of genetic and anatomicvariation of Cucurbitarootstockonvigour, survival and yield of graftedmelons. Journal of Horticultural Science \& Biotechnology 79(3): 370-374.

Fernández-García, N., Carvajal, M., Olmos, E. (2004): Graft union formation in tomato plants: peroxidase and catalase involvement. Ann. Botany 93: 53-60.

GARNER, R. (1979): Compatibility and cambial contact. New York: Oxford University Press, 49-67.

LEE, J. M. (1994): Cultivation of grafted vegetables I. Current status, grafting methods, and benefits. Hort Science 29(4): 235-239. 
NAGY, J. (2005): A sárga- és görögdinnye. Szaktudás Kiadó Ház Rt., Budapest. 3

Penella, C., Nebauer, S.G., Quinones, A., Bautista, A.S., Lopez-Galarza, S., Calatayud, A., (2014): Some rootstocks improve pepper tolerance to mild salinity through ionic regulation. Plant Sci. 230: 12-22.

PogONYI, Á., PÉK, Z. (2004): Zöldségnövények oltása. Hajtatás, korai termesztés, 35(2): 17-20.

SEDLÁK, L. (1993): A dinnye oltása. Kertészet ésSzőlészet. 43(11): 8-9. 